\title{
Implementation of 3M Learning Strategies (Imitating, Processing, Developing) in Writing Negotiating Texts for Class X Grade Students of SMK Cendana Padangpanjang
}

\author{
A. Anggeria ${ }^{1}$, Atmazaki $^{2}$, Abdurrahman $^{3}$ \\ \{afnianggeria@yahoo.com ${ }^{1}$, abdurahman.padang@gmail.com ${ }^{3}$ \} \\ ${ }^{1,2,3}$ Faculty of Language and Art, Universitas Negeri Padang, Padang, Indonesia
}

\begin{abstract}
This study aims to describe the Implementation of $3 \mathrm{M}$ Learning Strategies (Copying, Processing, Developing) in Writing Negotiating Texts for Class X Students of Cendana Padang Panjang Vocational School.This type of research is quantitative research with quasi-experimental methods (quasiexperimental). The research design used was One-Group Pretest-Posttest Design with purposive sample technique. The sample in this study amounted to 30 people drawn from the entire population. The instrument used in this study was a performance test. Data collection techniques in this study include: 1) Preliminary tests (pretest), 2) Student worksheets are collected, examined and scored, 3) Learn to write negotiating texts by applying the $3 \mathrm{M}$ strategy (imitating, processing, developing), 4 ) Conducted a final test (posttest) students write negotiating texts 5) Work sheets of students' posstest results are collected and assessed based on predetermined indicators. Data analysis techniques are: 1) reading and correcting students' writing according to indicators, 2) giving and recording scores, 3) changing scores into grades, 4) classifying, 5) determining mean scores, 6) hypothesis testing. The results of this study indicate that the application of the 3M Strategy (Imitation, Processing, Developing) significantly influences the ability to write negotiating texts for $\mathrm{X}$ grade students of TKJ 3 SMK Cendana Padangpanjang. Statistically shows that $\mathrm{t}$ arithmetic is greater than $t_{\text {table }}$ or $\mathrm{t}_{\text {table }}(9.54>1.70)$, then ( $\left.\mathrm{H} 0\right)$ is rejected, it can be concluded that the alternative hypothesis (H1) is accepted. Thus 3M's learning strategy (imitating, processing, developing) can improve student learning outcomes in writing negotiating texts.
\end{abstract}

KeyWord: 3M Learning, Negotiating Texts

\section{Introduction}

Indonesian Language Learning is one of compulsory learning at all levels of education. Indonesian Language Learning consists of language and literature learning. Language and literature learning is important to do, especially to improve the quality of education and create skilled people. Material in the language and literature fields is integratedly displayed in four language skills (listening, speaking, reading and writing). Writing is essentially the transfer of thoughts or feelings into the symbols of language. Thus, writing is an effort to transfer spoken language into written form by using written symbols. A good writer must be able to provide understanding through his writing to the reader.[1] 
There are 5 types of writing namely description, narration, exposition, argumentation and persuasion. Description is writing that describes an object. Narration is writing in the form of a story in the order of a series of events. Exposition means explaining, telling, or explaining something, so that the reader / listener understands and understands what is conveyed. Arguments are deviations aimed at convincing the reader or listener of the ideas or statements put forward. Persuasion is writing that seeks to persuade or invite the reader so that his ideas are followed by others through convincing words and sentences. [2]

Negotiation is a process of communication between sellers and prospective buyers both individuals and groups in which discussions and negotiations occur to reach an agreement on mutually beneficial goals for both parties. Negotiations are also two-way communication, namely the seller as a communicator and the buyer as a communicant or alternately.[3] Negotiation is a form of social interaction that functions to find a joint solution between parties who have different interests. These parties try to resolve the differences in good ways without harming either party. In negotiations, the parties try to resolve the differences through dialogue. [4] The purpose of the negotiating text was divided into;

(1) is considered important in the view of both parties,

(2) can lead to conflict between the two parties, and

(3) requires cooperation from both parties to achieve it. [5]

The purpose of people negotiating is to find an agreement between the two parties fairly and can meet the expectations or desires of both parties. In addition, the purpose of negotiations can also be to gain profits, avoid losses or solve other problems. The outcome of a negotiation is the existence of an agreement that benefits both parties. In the negotiation process, negotiations must understand the objectives and objectives of the other party. In this way, a new culture was created in the negotiations. The culture will have a major impact on the negotiation process and the resulting decisions. [6]

States that, the purpose of negotiations is essentially 1) resolving disputes because of differences of opinion, 2) negotiating to get an agreement, and 3) making agreements between the two parties. [7] The structure of negotiating texts is generally formed by three parts, namely:

1) opening, containing content or something that is considered a problem by one of the parties.

2) content, in the form of a bidding from both parties to find a mutually beneficial solution, until an agreement or disagreement is obtained.

3) closing, contains the agreement of both parties. Maybe in it there is also a thank you, hope, or other expressions as a sign of satisfaction or dissatisfaction. [8]

Negotiating the ability of persuasion is very much needed so that the negotiating text is also called a persuasive text. The structure of the negotiating text, namely:

1) a thesis that contains an introduction to the main idea of the author about a phenomenon that will be discussed

2) an argument that contains opinions that support the main idea of the author, and

3) recommendations that contain the invitation of the writer to the reader. [9]

The language characteristics of negotiating texts consist of three, namely the existence of speech pairs, using polite language, and using persuasive language. The words used to show politeness include: please, please, try, and may These words are actually words that are ordered but delivered persuasively. [10] The learning strategy is a learning activity that must be done by teachers and students so that learning objectives can be achieved effectively and efficiently. In the learning strategy contained the meaning of planning. That is, that the 
strategy is basically still conceptual about the decisions that will be taken in an implementation of learning.[11]

The 3M strategy (imitating-processing-developing) is a result of the development of the copy of the master strategy. Literally the master copy comes from English, which means it is a model to emulate. The model to be emulated is not only limited to lateral imitation but there is a phase of improvement. It is from this imitation to improvement stage that stands out in this strategy. Basically, this strategy requires exercises in accordance with the models offered. Then this strategy was developed into a simpler 3M strategy. 3M's strategy includes only three stages, namely the stage of imitating, processing, and developing. The $3 \mathrm{M}$ strategy stage refers to several stages of writing learning, namely imitating, processing, and developing.

In the following, some researchers about negotiating texts that have been conducted are Siti dan Jufri [12], Arianti [13], Hariyadi [14].

\section{Method}

This type of research is quantitative. It is said quantitative research because the data obtained from this researcher in the form of figures obtained from the final test results of writing skills in negotiating text of class $\mathrm{X}$ students of Cendana Padangpanjang. The population of this study is students of class X TKJ 3 SMK Cendana Padang Panjang registered in the 2017-2018 school year consisting of five classes totaling 154. Researchers took the sample of this study in class X TKJ 3 SMK Cendana Padang Panjang, amounting to 30 people. The variable of this research is the ability to write negotiating texts with subvariables before and after the Imitation, Processing, Developing (3M) strategies are applied. The instrument of this study is a performance test that contains an introduction to sample tasks that are seen from the aspect of indicators. Based on the test can be measured the ability to write negotiating texts. The test that will be given in this research is writing a negotiating text. The test is carried out twice, namely before and after the strategy of imitating, processing, developing $3 \mathrm{M}$.

According to test the hypothesis the following formula is used

$$
t=\frac{\left[\overline{\mathrm{X}}_{1}-\overline{\mathrm{X}}_{2}\right]}{\sqrt{\frac{s^{2}}{N_{1}}+\frac{s^{2}}{N_{2}}}}
$$

Information :

$1=$ posttest average score

$2=$ Pretest average score

$\mathrm{N}=$ Number of students

$\mathrm{S} 2$ = Combined standard deviation

\section{Result and Discussion}

The ability to write negotiating texts before implementing the $3 \mathrm{M}$ strategy is determined based on the assessment indicators used. In full, the acquisition of scores and the value of writing negotiating text skills before implementing the $3 \mathrm{M}$ strategy can be seen in the following table.

Tabel 4.1

Ability to Write Negotiating Texts of Class X TKJ 3 Students at SMK Cendana Padangpanjang before Implementing 3M Strategy 


\begin{tabular}{|c|c|c|c|c|c|}
\hline No & Indicator & Skor & Value & Frequency & Percentage \\
\hline \multirow[t]{3}{*}{1.} & Introduction & 3 & 100 & 11 & 36,67 \\
\hline & & 2 & 67 & 17 & 56,67 \\
\hline & & 1 & 33,33 & 2 & 6,67 \\
\hline \multirow[t]{3}{*}{2.} & Content & 3 & 100 & 5 & 16,67 \\
\hline & & 2 & 67 & 21 & 70 \\
\hline & & 1 & 33,33 & 4 & 13,33 \\
\hline \multirow[t]{3}{*}{3.} & Closing & 3 & 100 & 4 & 13,33 \\
\hline & & 2 & 67 & 20 & 66,67 \\
\hline & & 1 & 33,33 & 6 & 20 \\
\hline \multirow[t]{3}{*}{4.} & Using polite & 3 & 100 & 1 & 3,33 \\
\hline & languange & 2 & 67 & 22 & 73,33 \\
\hline & & 1 & 33,33 & 7 & 23,33 \\
\hline \multirow[t]{3}{*}{5.} & Using persuasive & 3 & 100 & - & - \\
\hline & santences & 2 & 67 & 7 & 23,33 \\
\hline & & 1 & 33,33 & 23 & 76,67 \\
\hline
\end{tabular}

Based on Table 4.1, the following three things can be described. First, for indicator 1 (Opening) 11 students were obtained (36.67\%). Second, a score of 2 with a value of 67 was obtained by 17 students (56.67\%). While a score of 1 with a value of 33.33 obtained 2 students (6.67). Indicator 2 (Content) is described in the following three terms. First, a score of 3 with a score of 100 was obtained by 5 students $(16.67 \%)$. Second, a score of 2 with a value of 67 was obtained by 21 people (70\%). Third, a score of 1 with a value of 33.33 obtained 4 students (13.33\%). Indicator 3 (Closing) is described the following three things. First, a score of 3 with a score of 100 was obtained by 4 students $(13.33 \%)$. Second, a score of 2 with a value of 67 was obtained by 20 people $(66.67 \%)$. Third, a score of 1 with a value of 33.33 obtained by 6 people (20\%). Indicator 4 (Using Polite Language) is described in the following three terms. First, a score of 3 with a score of 100 was obtained by 1 person (3.33\%). Second, a score of 2 with a value of 67 was obtained by 20 students $(66.67 \%)$. Third, a score of 1 with a value of 33.33 obtained by 7 people $(23.33 \%)$. Indicator 5 (Using Persuasive Sentences) is described first, a score of 2 with a value of 67 is obtained 7 students (23.33\%). two, a score of 1 with a value of 33.33 obtained 23 students $(76.67 \%)$.

The ability to write negotiating texts after the implementation of the 3M strategy is determined based on the assessment indicators used. In full, the acquisition of scores and the value of writing negotiating text skills after implementing the $3 \mathrm{M}$ strategy can be seen in the following table.

\section{Tabel 4.2}

Ability to Write Negotiating Texts of Class X TKJ 3 SMK Cendana Padangpanjang After Implementing 3M Strategy

$\begin{array}{llcccc}\text { No } & \text { Indicator } & \text { Skor } & \text { Value } & \text { Frequency } & \text { Percentage } \\ \text { 1. } & \text { Introduction } & 3 & 100 & 27 & 90 \\ & & 2 & 67 & 3 & 10 \\ & 1 & 33,33 & - & -\end{array}$




\begin{tabular}{|c|c|c|c|c|c|}
\hline \multirow[t]{3}{*}{2.} & Content & 3 & 100 & 30 & 100 \\
\hline & & 2 & 67 & - & - \\
\hline & & 1 & 33,33 & - & - \\
\hline \multirow[t]{3}{*}{3.} & Closing & 3 & 100 & 30 & 100 \\
\hline & & 2 & 67 & - & - \\
\hline & & 1 & 33,33 & - & - \\
\hline \multirow[t]{3}{*}{4.} & Using polite languange & 3 & 100 & 21 & 70 \\
\hline & & 2 & 67 & 9 & 30 \\
\hline & & 1 & 33,33 & - & - \\
\hline \multirow[t]{3}{*}{5.} & persuasive & 3 & 100 & 13 & 43,3 \\
\hline & santences & 2 & 67 & 17 & 56,67 \\
\hline & & 1 & 33,33 & - & - \\
\hline
\end{tabular}

Based on Table 4.2, the following two things can be described. First, for indicator 1 (Introduction) score 3 with a score of 100 obtained 27 students (90\%). Secondly, obtained a score of 2 with a value of 67 obtained by 3 students (10\%). Indicator 2 (Content) is described below. First, a score of 3 with a score of 100 was obtained by 30 students (100\%) .Indicator 3 (Closing) is described below. First, a score of 3 with a score of 100 was obtained by 30 students $(100 \%)$. Indicator 4 (Using Polite Language) is described in the following three terms. First, a score of 3 with a score of 100 was obtained by 21 students (70\%). Second, a score of 2 with a value of 67 was obtained by 9 students (30\%). Indicator 5 (Using Persuasive Sentences) is described in the following three terms. First, a score of 3 with a score of 100 was obtained by 13 students (43.33\%). Second, a score of 2 with a value of 67 was obtained by 17 students $(56.67 \%)$.

\section{Conclusion}

Based on the results of the data analysis and discussion in Chapter IV, that the data obtained on an average count the level of writing ability Negotiating text of class X students of TKJ 3 SMK Cendana Padangpanjang prior to implementing the $3 \mathrm{M}$ strategy is 61.7 namely for indicators:

a) Opening

b) Contents

c) Closing

d) Using Polite Language

e) Using Persuasive Sentences. From the average of these calculations it can be concluded that the ability to write a negotiating text for grade X TKJ 3 students of Padang Cendana Vocational High School prior to implementing the $3 \mathrm{M}$ strategy is sufficient, in the range of 56-75\% which is equal to (61.7).

Whereas the ability to write negotiating text for students of class X TKJ 3 of SMK Cendana Padangpanjang after applying the $3 \mathrm{M}$ strategy with indicators:

a) Opening

b) Contents

c) Closing

d) Using Polite Language

e) Using Persuasive Sentences. So based on the analysis of the data obtained, the average level of ability to write negotiating text for grade $\mathrm{X}$ students of TKJ 3 , SMK Cendana Padangpanjang after applying the 3M strategy was 93.09. From the 
average of these calculations it can be concluded that the ability to write negotiating text for class $\mathrm{X}$ students of TKJ 3 SMK Cendana Padang Panjang using the $3 \mathrm{M}$ strategy is very good (BS), in the range of 86-95 that is equal to (93.09).

Based on students' mastery of each indicator of the ability to write negotiating texts, it was concluded that the ability to write negotiating texts of class X TKJ 3 students at SMK Cendana Padang Panjang after implementing the 3M strategy was better and improved compared to before. Based on the results of the t-test, it was concluded that there was a significant effect of the implementation of the $3 \mathrm{M}$ strategy on the ability to write negotiating texts for Grade X TKJ 3 students of Cendana Padang Panjang Vocational School because of $t_{\text {count }}>t_{\text {table }}(9.54>1.70)$. So, it was concluded that the ability to write negotiating text for grade $\mathrm{X}$ TKJ 3 students at SMK Cendana Padangpanjang after applying the 3M strategy was better than before applying the $3 \mathrm{M}$ strategy. So by choosing the $3 \mathrm{M}$ strategy to be the choice because, so far our education is still dominated by the view that knowledge as a set of facts must be memorized. The class still focuses on the teacher as the main source of knowledge, then lectures become the main choice of learning strategies. For this reason, a learning strategy or technique is needed that does not require students to memorize facts, but a model that requires students or encourages students to produce knowledge in their own minds. Through this $3 \mathrm{M}$ strategy students are expected to learn to imitate, write, not memorize. So that the implementation of learning controlled by the teacher the learning atmosphere will be fun, not monotonous, and students are comfortable in learning and provide an increase in the ability to write student negotiating texts.

\section{References}

[1] Semi, Atar 2009 Menulis Efektif. Padang: UNP Press.

[2] Atmazaki 2009 Kiat-Kiat Mengarang dan Menyunting. Padang: UNP Press.

[3] Kemendikbud. Buku Peserta Didik Bahasa Indonesia: Ekspresi Diri dan Akademik. Jakarta: Kementrian Pendidikan dan Kebudayaan

[4] Nurjaman Kadar dan Khairul Ummam 2012 Komunikasi Publik Relation. Bandung: Pustaka Setia.

[5] Varner, Iris 2013 “The Role of Negotiation in Intercultural Bussines Communitation”. International Frofessional Journal, (1): 139-145.

[6] Yuniawan, Tommi 2012 Terampil Retorika Berbicara. Semarang: Unes Press.

[7] Kosasih 2014 Jenis-Jenis Teks (Analisis Fungsi, Struktur, dan kaidah Serta Langkah Penulisannya). Bandung: Yrama Wisya

[8] Kemendikbud. Bahasa Indonesia Ekspresi Diri dan Akademik. Jakarta: Kementrian Pendidikan dan Kebudayaan.

[9] Hosnan. Pendekatan Saintifik dan Kontekstual dalam Pembelajaran Abad 21. Bogor: Ghalia Indonesia

[10] Hadi, A Soedomo 2008 Pendidikan (Suatu Pengantar). Surakarta: Lembaga Pengembangan Pendidikan (LPP) UNS dan UPT Penerbit dan Pencetakan UNS (UNS Press).

[11] Marahimin, Ismail 2004 Menulis secara Populer. Jakarta: PT Dunia Pustaka Jaya.

[12] Sitti Dan Jufri 2014 Peningkatkan Kemampuan Menulis Teks Negosiasi Dengan Menggunakan Model Jigsaw. Jurnal.Untan.Ac.Id/Index.Php/Jpdpb/Article/View/12377

[13] Arianti 2017 Peningkatan Kemampuan Menulis Teks Negosiasi Dengan Menggunakan Metode Inquiry. Https://Jurnal.Unigal.Ac.Id/ Index.Php/Diksatrasia/Article/ Download/643/545 
[14] Haryadi 2017 Peningkatan Keterampilan Memproduksi Teks Negosiasi Lisan Menggunakan Metode Pasar Kelas Dengan Media Audio Visual Pada Peserta Didik $\begin{array}{llllll}\text { Kelas } \mathrm{X} & \text { Social Science-2 SMA Negeri } 3 & \text { Slawi. }\end{array}$ https://journal.unnes.ac.id/sju/index.php/jpbsi/article/download/11218/9625/ 